\title{
COMPLICATIONS OF NON-ENDOSCOPIC DISCECTOMY: A RETROSPECTIVE STUDY OF TWENTY-ONE YEARS
}

\author{
COMPLICAÇÕES DA DISCOTOMIA NÃO ENDOSCÓPICA: ESTUDO RETROSPECTIVO \\ DE VINTE E UM ANOS
}

\section{COMPLICACIONES DE LA DISCECTOMÍA NO ENDOSCÓPICA: ESTUDIO RETROSPECTIVO DE VEINTIÚN AÑOS} \author{
Nicolás Prada Ramírez ${ }^{4}$, Gabriel Oswaldo Alonso Cuéllar ${ }^{1}$ \\ 1. Spine Group Research of Centro de Columna - Cirugía Mínima Invasiva, Bogotá, Colombia \\ 2. Centro de Cirugía de Mínima Invasión (Cecimin), Bogotá, Colombia. \\ 3. Clínica Reina Sofía, Organización Sanitas Internacional, Bogotá, Colombia. \\ 4. Clínica Foscal Internacional, Bucaramanga, Colombia.
}

Jorge Felipe Ramírez león ${ }^{1,2,3}$, José Gabriel Rugeles Ortiz ${ }^{1,2,3}$, Enrioue Osorio Fonseca ${ }^{1,2,3}$, Carolina Ramírez Martínez ${ }^{1,2,3}$,

\begin{abstract}
Objective: To report and compare the number and grade of major complications presented with non-endoscopic thermal discectomy and nucleoplasty for the treatment of discogenic axial lumbar pain using laser and radiofrequency. Methods: A 21 years retrospective study was conducted of the clinical charts of patients whose reason for consultation was axial lumbar pain from degenerative disc disease, and who underwent surgery using non-endoscopic discectomy and nucleoplasty (NEDN). Two groups were established; the first, NEDN with laser, and second, NEDN with radiofrequency. The number and types of complications reported in the case-series were counted, and their statistical differences determined. Results: The inclusion criteria were fulfilled by 643 of the medical charts. 26 complications were reported, the most common being radiculitis $(n=12)$. Statistically significant differences were found between the complications occurring in the two groups $(p=0.01)$. Conclusion: The number of complications showed statistically significant difference. The severity of the complications and adverse outcomes provide an argument for choosing one technology over the other. Training and the learning curve stage are important factors to be taken into account, to avoid complications.
\end{abstract}

Keywords: Diskectomy; Pulsed radiofrequency treatment; Laser therapy; Low back pain.

\section{RESUMO}

Objetivo: Relatar e comparar o número e grau das complicações importantes apresentadas com discotomia e nucleoplastia térmica não endoscópica no tratamento da dor lombar axial discogênica usando laser e radiofrequência. Métodos: Estudo retrospectivo de 21 anos, realizado com os prontuários clínicos de pacientes cujo motivo da consulta foi dor lombar axial por doença degenerativa do disco, que foram submetidos a cirurgia empregando discotomia e nucleoplastia não endoscópica (NEDN). Dois grupos foram estabelecidos, o primeiro, NEDN com laser e o segundo, NEDN com radiofrequência. O número e os tipos de complicações relatadas na série de casos foram contabilizados, e suas diferenças estatísticas foram determinadas. Resultados: Os critérios de inclusão foram satisfeitos por 643 prontuários clínicos. Foram relatadas 26 complicações, sendo a mais comum a radiculite $(n=12)$. Foram encontradas diferenças estatisticamente significativas $(p=0,01)$ entre as complicações que ocorreram nos dois grupos. Conclusão: 0 número de complicações mostrou diferença estatisticamente significativa. A gravidade das complicações e os resultados adversos fornecem um argumento para a escolha de uma tecnologia sobre a outra. O treinamento e a curva de aprendizagem são fatores importantes a considerar para evitar complicações.

Descritores: Discotomia; Tratamento por radiofrequência pulsada; Terapia a laser; Dor lombar.

\section{RESUMEN}

Objetivo: Relatar y comparar el número y grado de las complicaciones importantes que se presentaron con la discectomía y nucleoplastia térmica no endoscópica para el tratamiento del dolor lumbar axial discogénico utilizando láser y radiofrecuencia. Métodos: Estudio retrospectivo de 21 años de las historias clínicas de pacientes cuyo motivo de consulta fue el dolor lumbar axial debido a enfermedad degenerativa del disco, que fueron sometidos a cirugía mediante discectomía y nucleoplastia no endoscópica (NEDN). Se establecieron dos grupos, el primero, NEDN con láser y el segundo, NEDN con radiofrecuencia. Se contaron el número y los tipos de complicaciones relatadas en la serie de casos, y se determinaron sus diferencias estadísticas. Resultados: Los criterios de inclusión fueron satisfechos por 643 historias clínicas. Se encontraron 26 complicaciones, siendo la más común la radiculitis $(n=12)$. Se encontraron diferencias estadísticamente significativas entre las complicaciones ocurridas $(p=0,01)$. Conclusión: El número de complicaciones mostró una diferencia estadísticamente significativa. La gravedad de las complicaciones y los resultados adversos proporcionan un argumento para elegir una tecnología sobre la otra. La capacitación y la curva de aprendizaje son factores importantes a tener en cuenta para evitar complicaciones.

Descriptores: Discectomía; Tratamiento de radiofrecuencia pulsada; Terapia por láser; Dolor de la región lumbar. 


\section{INTRODUCTION}

Discogenic pain is defined as back pain caused by disc degeneration. ${ }^{1}$ Currently, there are different alternatives for the treatment of discogenic pain. Options range from conservative medical management to open arthrodesis. ${ }^{2}$ In some studies, minimally invasive spine surgery (MISS) has evidenced similar clinical results to conventional surgery, with benefits inherent to a smaller access, such as reduced trauma in the tissues adjacent to the disc lesion, skin incisions of less than $1 \mathrm{~cm}$, the possibility of using local anesthetic and sedation only, less blood loss, shorter hospitalization times, faster recovery, and earlier return to work. ${ }^{3-5}$ One of the MISS procedures most widely used in the treatment of discopathy is non-endoscopic thermal discectomy and nucleoplasty (NEDN) ${ }^{6,7}$ This technique consists of the placement of non-endoscopic fibers to transmit thermal energy and increase temperature in the intradiscal zone, causing the ablation of pain generating nerves, ${ }^{6}$ complemented by decompression with mechanical nucleoplasty. ${ }^{7,8}$

Since its description by Hijikata, ${ }^{9}$ and its complementing with thermal energy by Choy et al., ${ }^{10}$ this technique has been implemented in more than 500,000 patients around the world. ${ }^{11}$ The principle behind the treatment is that it produces sufficient intradisc temperatures to achieve annular collagen shrinkage, nucleus dehydration, and nociceptor ablation in the posterior annulus area, with resulting pain relief. ${ }^{12}$ Most fibers use either laser (LS) or radiofrequency (RF) as the heat source. ${ }^{5}$ The effectiveness of both LS and RF has been reported in several studies, with improvement rates of above $70 \%, 7,8,11,13-21$ Nevertheless, their safety margin and degree of complications continue to create extensive controversies between different surgeons. The purpose of the study was to report and compare the number and grade of major complications present in non-endoscopic thermal discectomy and nucleoplasty, in the treatment of discogenic axial lumbar pain using LS and RF technologies.

\section{MATERIALS AND METHODS}

This is a retrospective study reviewing medical charts of patients treated with NEDN that reported any type of major complication associated with the procedure between 1993 and 2014. The study only included patients whose reason for consultation was axial lumbar pain, and whose final diagnosis was either degenerative disc disease (DDD), black disc, disc bulging, annular tear, or contained herniated disc. The disease was diagnosed by history, clinical examination, plane and dynamic X-ray and MRI. Also, for inclusion of the record in the study, the surgical notes had to report at least one positive discogenic test $(\geq 5 / 10)$. Medical records were excluded belonging to patients with pathologies such as discopathy with more than $50 \%$ height loss, any degree of segmental instability, or positive discography not consistent with lumbar symptoms, radicular pain, and medical charts with incomplete data on follow-up and evaluation criteria. The study was not submitted to the ethics committee.

\section{Setting and surgical procedure}

Surgeries were performed at the Reina Sofia Clinic in Bogotá Colombia, by the same team of surgeons and using a standardized technique, with minor changes throughout the experience. The source of laser energy used was the Holmium YAG Laser (Trimedyne Inc. Irvine, CA). The RF electrode employed was DiscFX Bipolar System (Elliquence, NYC, NY) and a high-frequencylow temperature radiofrequency energy source called Surgimax (Elliquence LLC, NYC), in bipolar mode.

The patient was placed in the prone position. An epidural needle was inserted at a $45^{\circ}$ angle in the direction of the foraminal area, 8 $\mathrm{cm}$ to $12 \mathrm{~cm}$ from the midline. The aim was for the tip of the needle to enter the posterior third of the intervertebral space. After determining whether the level tested during the discography procedure reproduces the patient's familiar, concordant pain (positive result), we entered the disc through a system of dilator, cannulas and trephines. These elements was placed sequentially, always under the verification of the fluoroscope, to reach the annulotomy and enter the nucleus. In order to allow adequate access to the fiber and achieve neural decompression, a nuclear resection was performed. This mechanical discectomy was performed using the punch forceps. Lastly, an electrode was inserted, and the thermal discectomy and nucleoplasty was performed.

\section{Clinical evaluation}

"Major related complications" designates the presentation, during the intraoperative period and up to three months after NEDN, of phenomena such as transient or definitive motor deficit, dural tear, headache, radiculitis, chemical discitis, or vertebral end-plate burning, and infectious spondylodiscitis.

To minimize bias, including among observers, a company independent from the researchers conducted the review of medical records and gathered data from the patients with major complications.

\section{Statistical analysis}

Data analysis was performed with the statistical software R 3.1.1 for Windows 8. The analysis determined certain aspects in the variables, including frequency and descriptive statistics. The tests selected for to compare the groups were $X^{2}$ and Wilcoxon for related pairs. Statistical significance was $p<0.05$.

\section{RESULTS}

The inclusion criteria were fulfilled by 643 of the medical charts. Table 1 shows the statistical demographic data of the entire sample. Across the sample, 849 discs (discography-positive) were treated, showing a rate of 1.32 interventions per patient. The most affected levels were L4-L5 (329) and L5-S1 (296), comprising up to 73.7\% of the total intervened discs; followed by L3-L4 (154), L2-L3 (53), and lastly, L1-L2 (17).

LS was used from March 1993 to January 2008. The inclusion criteria were fulfilled by 171 medical charts. In turn, RF was applied between January 2008 and March 2014, and 472 medical charts met the inclusion criteria. In twenty-one years, a total of 26 major complications were reported.

For the 171 medical charts that fulfilled the inclusion criteria, complications occurred in $10.53 \%$ of the patients $(n=18)$ when LS was used. The distribution of these complications was: motor deficit $(n=2)$, one of them definitive with dorsiflexor paresis (2/5); headache caused by dural sac tear $(n=2)$; post-operative radiculitis $(n=8)$; chemical discitis or vertebral end-plate burning with the laser light $(n=4)$, and infectious spondylodiscitis $(n=2)$.

In turn, in the 472 medical charts where RF was used, the ratio was $1.69 \%$. These included transient motor deficit $(n=1)$, dural tear headache $(n=1)$, postoperative radiculitis $(n=4)$, and infectious spondylodiscitis $(n=2)$. No chemical discitis was reported.

The differences in the presentation of complications were statistically significant $(p=0.01)$.

Table 1. Sex and age distribution of the population.

\begin{tabular}{c|c|c|c|c|c}
\hline \multicolumn{2}{c|}{ Sex $\%(\mathbf{n})$} & \multicolumn{4}{c}{ Age (Years) } \\
\hline Male & Female & Youngest & Oldest & Average & SD \\
\hline $50.3(324)$ & $49.6(319)$ & 24.1 & 86 & 50.9 & 12.24 \\
\hline
\end{tabular}

\section{DISCUSSION}

The number and type of complications are important in determining the safety of a surgical procedure. Several factors can increase the possibility of complications: wrong choice of patient, poor technique, being in initial stages of the learning curve, and certain concomitant diseases. ${ }^{22}$ To the best of our knowledge, no publication has compared complications presented with percutaneous disc decompression between two analog technologies such as LS and RF, performed by the same surgical team, in the treatment of discogenic pain. Thus, it is important to analyze factors such as 
type, severity and solution of the complication, and the learning curve stage in which such complication occurred.

The percentage of complications in the global sample (LS+RF) was $4.0 \%(26 / 643)$, which could be deemed high if reports that fall below $1 \%$ are considered. ${ }^{18,19,23}$ We hypothesize that because of the complications, the medical charts may have been completed in greater detail, always complying with the "complete data on follow-ups and evaluation" inclusion criteria. Thus, the relation of the complications to the number of patients without complications led to a number of compliant records that was less than the total number of patients treated in the 21 years of the experience $(n=1,357)$, therefore the resulting percentage was higher. Thus, if the study links complications to the total number of patients, this gives a global percentage of $1.9 \%$, which is more like the percentage reported in general in the literature.

Another interesting data was that $69 \%$ of the complications (18/26) occurred in the initiation stage of the learning curve with LS. This result could be associated with factors such as the learning curve development and the high temperatures reached with this technology. Indeed, these factors caused the complication percentage with LS to become $10.4 \%$, a figure that is considerably higher than cited in reports by authors who use the same technology, which is below $1 \%{ }^{16}$ In contrast, the RF results differed $(1.7 \%)$ due to factors such as the lower temperatures reached by the technology, the advanced learning curve stage, and the higher number of medical records that met the inclusion criteria and were comparable with the percentages reported in the literature. ${ }^{7,17-19}$

Regarding the type of complication, for laser, the literature reports spondylodiscitis as the most common, with an occurrence ranging from $0.24 \%$ to $1.2 \% .{ }^{15,16,24}$ In contrast, this series shows radiculitis as the principal complication. This complication is related to the initial stages of the learning curve, incorrect (too deep) anesthesia protocol, and excessive heat from fibers with low irrigation. Concerning the use of RF with the same system used in this case-series, to our knowledge, this type of complication was not reported. With other RF available systems, minor complications have been reported, such as discomfort in the area of the incision, numbness, and leg weakness. ${ }^{25,26}$

In regard to types of complications, a sudden change is evident in the use and preference of RF over LS, due precisely to the number of complications and their nature and severity, specifically in the presentation of "thermal necrosis of vertebral endplate." This complication continues to occur even in the advanced stages of the learning curve. ${ }^{16}$ It is also important to mention that of the $26 \mathrm{com}$ plications presented in this sample, only one - a permanent motor deficit caused by thermal L5 root lesion with dorsiflexor paresis - did not respond to standard medical treatment, and the remaining 25 patients were treated and resolved. Chemical discitis only appeared upon using LS $(n=4)$ and constituted with the definitive motor deficit, one of the reasons for assessing the effectiveness and safety of RF.

\section{CONCLUSION}

MISS has been reported as a group of effective and safe procedures. Nevertheless, there are several factors that could increase the rate of complications. In this series, we concluded that the training and learning curve stages are important factors to take into account. Also, it must be noted that whereas the two techniques have proven to be effective in the treatment of discogenic lumbar axial pain, in this sample, the occurrence of complications was different and statistically significant. Likewise, the severity of the complications, and their negative outcome, provide an argument for choosing one technology over the other.

Dr. Ramírez, Dr. Rugeles, Dra. Ramírez and Dr. Prada are consultant for Elliquence. Dr. Osorio and Dr. Alonso report no conflicts.

CONTRIBUTIONS OF THE AUTHORS: Each author contributed individually and significantly to the development of the manuscript. JR and GA were the main contributors to the writing of the manuscript. JR, JGR, and CR performed the surgery and patient follow-up, and gathered the clinical data. JR, NP and GA evaluated the data from the statistical analysis. GA, EO and NP performed the literature review and review of the manuscript and contributed to the intellectual design of the study.

\section{REFERENCES}

1. Singh V. Scientific basis for nucleoplasty. Tech Reg Anesth Pain Manag. 2005;9(1):13-24.

2. Davis TT, Sra P, Fuller N, Bae H. Lumbar intervertebral thermal therapies. Orthop Clin North Am. 2003;34(2):255-62.

3. Ruetten S, Komp M, Merk H, Godolias G. Full-endoscopic interlaminar and transforaminal lumbar discectomy versus conventional microsurgical technique: a prospective, randomized, controlled study. Spine (Phila Pa 1976). 2008:33(9):931-9.

4. Rasouli MR, Rahimi-Movaghar V, Shokraneh F, Moradi-Lakeh M, Chou R. Minimally invasive discectomy versus microdiscectomy/open discectomy for symptomatic lumbar disc herniation. Cochrane Database Syst Rev. 2014:(9):CD010328.

5. Dasenbrock HH, Juraschek SP, Schultz LR, Witham TF, Sciubba DM, Wolinsky JP, et al. The efficacy of minimally invasive discectomy compared with open discectomy: a meta-analysis of prospective randomized controlled trials. J Neurosurg Spine. 2012;16(5):452-62.

6. Gangi A, Basile A, Buy X, Alizadeh H, Sauer B, Bierry G. Radiofrequency and laser ablation of spinal lesions. Semin Ultrasound CT MR. 2005;26(2):89-97.

7. Hellinger S. Disc-FX - A treatment for discal pain syndromes combining a manual and radiofrequency-assisted posterolateral microtubular decompressive nucleotomy. Eur Musculoskelet Rev. 2011;6:2-8.

8. Osorio E, Ramírez J, Rugeles J Alonso G. Endoscopy and thermodiscoplasty: a minimally invasive surgical treatment for lumbar pain. In: Ramina R, Pires Aguiar PH, Tatagiba $M$, editors. Samii's Essentials in neurosurgery. 2nd ed. Berlin: Springer; 2014. p. 103-15.

9. Hijikata S. Percutaneous nucleotomy. A new concept technique and 12 years' experience. Clin Orthop Relat Res. 1989:(238):9-23.

10. Choy DS, Ascher PW, Ranu HS, Saddekni S, Alkaitis D, Liebler W, et al. Percutaneous laser disc decompression. A new therapeutic modality. Spine (Phila Pa 1976). 1992:17(8):949-56.

11. Reddy AS, Loh S, Cutts J, Rachlin J, Hirsch JA. New approach to the management of acute disc herniation. Pain Physician. 2005;8(4):385-90.

12. Ramírez-León JF, Rugeles-Ortiz JG, Barreto-perea JA, Alonso-cuéllar GO. Intradiscal temperature variation resulting from radiofrequency thermal therapy. Cadaver study. Acta Ortop Mex. 2014;28(1):12-8

13. Ramirez J Rugeles J Discolisis percutánea endoscópica lumbar con Holmium YAG Laser. Experiencia de 4 años. Rev Col Ort Traum. 2001;15(1):57-62.

14. Knight M, Goswami A. Lumbar percutaneous KTP532 wavelength laser disc decompression and disc ablation in the management of discogenic pain. J Clin Laser Med Surg. 2002;20(1):9-13.

15. Finch PM, Price LM, Drummond PD. Radiofrequency heating of painful annular disruptions: one-year outcomes. J Spinal Disord Tech. 2005;18(1):6-13

16. Choy DS. Percutaneous laser disc decompression: a 17-year experience. Photomed Laser Surg. 2004:22(5):407-10.

17. Hellinger $\mathrm{S}$. Treatment of contained lumbar disc herniations using radiofrequency assisted micro-tubular decompression and nucleotomy: four year prospective study results. Int J Spine Surg. 2014:8. doi: 10.14444/1024. eCollection 2014

18. Kumar N, Kumar A, Siddharth M S, Sambhav P S, Tan J. Annulo-nucleoplasty using DiscFX in the management of lumbar disc pathology: early results. Int J Spine Surg. 2014;8. doi: 10.14444/1018. eCollection 2014

19. Liao $X$, Jiang J, Xiong D, Yi W, Zhang $Q$, Zheng $H$, et al. The comparison of clinical outcomes of percutaneous lumbar discectomy with DiscFX System with fenestration and decompression for contained lumbar disc herniation (LDH) with radicular pain. Chinese J Pain Med. 2011:17(1):31-5.

20. Alfaro H, Ramos A. Treatment of lumbar hernias by endoscopic nucleoplasty with radiofrequency. Coluna/Columna. 2016;15(1):36-9.

21. Siebert WE, Berendsen BT, Tollgaard J. Percutaneous laser disk decompression. Experience since 1989. Orthopade. 1996;25(1):42-8

22. Ahn Y. Transforaminal percutaneous endoscopic lumbar discectomy: technical tips to prevent complications. Expert Rev Med Devices. 2012:9(4):361-6.

23. Grönemeyer DH, Buschkamp H, Braun M, Schirp S, Weinsheimer PA, Gevargez A. Image-guided percutaneous laser disk decompression for herniated lumbar disks: a 4-year follow-up in 200 patients. J Clin Laser Med Surg. 2003:21(3):131-8.

24. Hellinger J. Complications of non-endoscopic percutaneous laser disc decompression and nucleotomy with the neodymium: YAG laser $1064 \mathrm{~nm}$. Photomed Laser Surg 2004;22(5):418-22

25. Pevsner Y, Shabat S, Catz A, Folman Y, Gepstein R. The role of radiofrequency in the treatment of mechanical pain of spinal origin. Eur Spine J. 2003;12(6):602-5.

26. Gerszten PC, Smuck M, Rathmell JP, Simopoulos TT, Bhagia SM, Mocek CK, et al. Plasma disc decompression compared with fluoroscopy-guided transforaminal epidural steroid injections for symptomatic contained lumbar disc herniation: a prospective, randomized, controlled trial. J Neurosurg Spine. 2010;12(4):357-71. 